\title{
Enhancing the Nutrient Uptake and Quality of Pearlmillet (Pennisetum glaucum L.) through Use of Biofertilizers
}

\author{
Durgesh Singh $^{1^{*}}$, Krishna Raghuvanshi ${ }^{2}$, Asheesh Chaurasiya ${ }^{1}$, \\ Swaraj Kumar Dutta ${ }^{1}$ and Santosh Kumar Dubey ${ }^{1}$ \\ ${ }^{1}$ Department of Agronomy, BAU, Bhagalpur - 813210, India \\ ${ }^{2}$ Department of Agronomy, SHUATS, Allahabad - 211007, India \\ *Corresponding author
}

\section{A B S T R A C T}

\begin{tabular}{|c|}
\hline Keywords \\
\hline $\begin{array}{l}\text { Pseudomonas fluorescens, } \\
\text { Azotobacter chroococcum, } \\
\text { Azospirillum lipoferum, } \\
\text { Acetobacter diazotrophicus, } \\
\text { Trichoderma viride and Pearl } \\
\text { millet }\end{array}$ \\
\hline Article Info \\
\hline $\begin{array}{l}\text { Accepted: } \\
26 \text { March } 2018 \\
\text { Available Online: } \\
10 \text { April } 2018\end{array}$ \\
\hline
\end{tabular}

Inoculation of biofertilizers leads to reduction of chemical fertilizer requirement by fixation \& solubilisation of plant nutrients and thus, may able to maximize plant growth, yields and quality of output.To study the beneficial effect of biofertilizers on performance of pearlmillet (Pennisetum glaucum L.) a field experiment was conducted in randomized block designduring the rainy (Kharif) season of 2014 at Sam Higginbottom University of Agriculture, Technology and Sciences, Allahabad, India.Seeds of pearlmillet were treated with diazotrophic bacteria namely- Pseudomonas fluorescens, Azotobacter chroococcum, Azospirillum lipoferum, Acetobacter diazotrophicus and one fungi-Trichoderma viride @ 10-25 $\mathrm{g} \mathrm{kg}^{-1}$ alone and in combinations. The combined treatment with all the bioinoculants enhanced the grain yield (44\%), nutrient uptake ( $\mathrm{N}$ by $79.9 \%$ and $\mathrm{P}$ by $87.9 \%$ ) and grain quality (Protein by $58.9 \%$ and carbohydrate by 17\%), single inoculation was also found profitable over the control (Un-inoculated). Therefore, inoculation of pearlmillet seed with different biofertilizers could produce pollution free and healthy (better quality) food for increasing population and may able to reduce chemical fertilizer application without any significant reduction in grain yield.

\section{Introduction}

Pearlmillet [Pennisetum glaucum (L.)] is a drought tolerant, warm season cereal crop, largely grown for grain and fodder purpose and ranking sixth in the world following rice, wheat, corn, barley and sorghum. Pearlmillet can be grown in areas which are very hot, dry and soils having very poor organic matter, low water holding capacity and high infiltration rate. It can also grow in areas receiving less than $400 \mathrm{~mm}$ annual precipitation, which limit the growth of other cereal crop, due to its well-developed deep root system, short life cycle and fast growing habit. India is the major pearlmillet producing country in the world with Rajasthan sharing the major production (46\%) followed by Maharashtra (19\%), Gujarat (11\%), Uttar Pradesh (8\%) and Haryana (6\%) (Sonawane et al., 2010). Pearlmillet grain contains about 13-14 per cent protein, 5-6 per cent fat, 74 per cent carbohydrate, 1-2 per cent minerals and higher amount of carotene, riboflavin (Vitamin $\mathrm{B}_{2}$ ) 
and niacin (Vitamin $\mathrm{B}_{4}$ ) (Singh et al., 2009). High yielding potential along with nutritional features make pearl millet an important cereal crop that can effectively address the emerging challenges of food and nutritional security, global warming, water shortages and land degradation.

Pearlmillet crop is generally grown in marginal and sub-marginal lands (Parihar et al., 2010). Farmers often targeting higher yields tend towards higher use of fertilizers which often remains under-utilized in soils. Moreover, chemical fertilizers used to supply nutrients results, more cost of cultivation and severe environmental pollution (Dai et al., 2004) and also deteriorate the grain quality (Scheiner et al., 2002). Previous research provides ample evidence that a part of those harmful fertilizers can be replaced by biofertilizers (El Kholy et al., 2005). Compared to chemical fertilizers, biofertilizers are cost effective, renewable and eco-friendly sources of nutrient supply. Nitrogen fixer (Mrkovacki and Milic, 2001; Chen, 2006), phosphate and other nutrient solubilizing microorganisms (Cattelan et al., 1999) play an important role in supplementing nutrient to the plant, allowing a sustainable use of nitrogen and phosphate fertilizers (Tambekar et al., 2009). Certain strains are referred to as plant growth promoting rhizobacteria (PGPR), which can be used as inoculant biofertilizers (Kennedy et al., 2004) are: Pseudomonas, Bacillus, Azospirillum, Azotobacter, Burkholdaria, Rhizobium, Erwinia, Mycobacterium and Flavobacterium. Some species of Azotobacter and Azospirillum bacteria are able to provide beneficial effect on plant growth and pest resistance (Lugtenberg et al., 2002) directly and/or indirectly (Persello-Cartieaux et al., 2003; Nelson, 2004). Biofertilizers colonizes the rhizosphere and promotes growth and yield (Salantur et al., 2006) by enhancing the germination (Raju et al., 1999; Niranjan et al.,
2003; Niranjan et al., 2004) availability and supply of nutrients, along with production of antibiotic (Zahir et al., 2004) and phytohormones (Egamberdiyeva, 2007) to crop when the seed is treated or with soil application. Pearl millet and sorghum crops inoculated with Azotobacter and Azospirillum recorded 11-12\% increased yields in dryland condition (Wani, 1990). Acetobacter sp. is a new nitrogen fixing bacterium, isolated from sugarcane (Sharma, 2012) which act as a biofertilizers and enhance the performance of different crops with less fertilizer use (Jhala et al., 2014). Hungria et al., (2010) and Mellado et al., (1998) reported Azospirillum and Acetobacter as best endophytic $\mathrm{N}$ fixers in maize crop. Trichoderma sp. is also helpful for enhancing the growth, productivity and health (Harman, 2006) by increasing the accessibility of plant nutrients, minerals (Fe, $\mathrm{N}, \mathrm{P}$ ), production of growth hormones (Kaewchai et al., 2009), providing protection against drought stress (Mastouri et al., 2010), mycoparasitism, production of antibiotics and alter plant gene expression for inducing resistance in plants against several diseases (Alfano et al., 2007; Pandya and Saraf, 2010).

Inoculation of nitrogen fixing and phosphate solubilising microorganisms alone or in combination increase plant height, number of tillers and ultimately the yield (Saxena, 1997) and reduce the use of chemical fertilizers to supply nutrient requirement of the pearl millet (Aggarwal and venkateswarlu 1989). ElKholy and Gomaa (2000) and Urquiaga et al., (1992) have succeeded in reducing the recommended doses of chemical fertilizers needed for corn and millet by $50 \%$ using biofertilizers without any loss in yield. There are studies elucidating the effect of biofertilizers alone or in combination with other chemical fertilizers (Ram Rao et al., 2007; Seema et al., 2000). However, a systematic study involving both bacterial and fungal strains as inoculants is very meagre. 
The aim of the present study was to explore the possibilities of which single biofertilizers or combination of different biofertilizers gave the best results in terms of yield, nutrient uptake and quality of pearlmillet crop.

\section{Materials and Methods}

\section{Experimental site}

A field experiment was carried out at Crop Research Farm, Department of Agronomy, Allahabad School of Agriculture, SHUATS, Allahabad (U.P.), located at $25^{\circ} 24^{\prime} 42^{\prime \prime} \mathrm{N}$ latitude, $81^{\circ} 50^{\prime} 56^{\prime \prime} \mathrm{E}$ longitude and $98 \mathrm{~m}$ altitude above the mean sea level, during the rainy (Kharif) season of 2014 to assess the effects of biofertilizers on performance of pearlmillet crop (Pennisetum glaucum L.). The soil was sandy loam in texture, with $\mathrm{pH}$ 7.4 , organic carbon $0.32 \%$, low available $\mathrm{N}$ $188.3 \mathrm{~kg} \mathrm{ha}^{-1}$, medium available $\mathrm{P} 34.5 \mathrm{~kg}$ $\mathrm{ha}^{-1}$, available $\mathrm{K} 130.5 \mathrm{~kg} \mathrm{ha}^{-1}$. The total rainfall received during the crop season was $48.86 \mathrm{~mm}$.

\section{Experimental treatments}

Pearlmillet variety, UMA 7111(duration- 8590 days) was treated with the diazotrophic bacteria namely- Pseudomonas fluorescens, Azotobacter chroococcum, Azospirillum lipoferum, Acetobacter diazotrophicus, and one fungi- Trichoderma viride alone and in combinations@10-25 $\mathrm{g} \mathrm{kg}^{-1}$, and sown in randomized block design with three replications. The net plot area was $9 \mathrm{~m}^{2}$ and inoculated seeds were sown (below $1 \mathrm{~cm}$ ) at row spacing of $45 \mathrm{~cm}$. while, plant to plant spacing was $15 \mathrm{~cm}$. Nitrogen and phosphorus were applied uniformly to each treatment including control @ 50 and $30 \mathrm{~kg} \mathrm{ha}^{-1}$ (50 percent of RDF) through urea and diammonium phosphate respectively. Whole amount of nitrogen and phosphorus was applied at 15 DAS because it affects the establishment and multiplication of biofertilizers, if applied at the time of sowing. To assess the effects of biofertilizers, different treatments were worked at after harvest. The grain yields were recorded on plot basis and then converted in to $\mathrm{q} \mathrm{ha}^{-1}$. For nutrient content determination, nitrogen content was determined by Kjeldahl method using alkaline permanganate (Subbiah and Asija, 1956) and phosphorus levels by Olsen's method, 1954, protein content was determined by Lowry et al., 1951 method and carbohydrate by Colorimetric method. The nutrient uptake by the crops was obtained as the product of concentration of nutrient and yield. Analysis of variance (ANOVA) was done as per the procedure outlined by Gomez and Gomez (1984). The significant differences between treatments were compared with the least significance (LSD) at 5\% level of probability.

\section{Results and Discussion}

\section{Influence of biofertilizers on nutrient content and uptake}

In the present study it was observed that combination of different biofertilizers was able to increase $\mathrm{N}$ and $\mathrm{P}$ content in grain and stover significantly (Table 1 ). The maximum $\mathrm{N}$ content $(1.96 \%$ in grain \& $0.74 \%$ in stover) and $\mathrm{P}$ content was found $(0.306 \%$ in grain \& $0.081 \%$ in stover) with treatment, P.fluorescens + A. chroococcum $+A$. lipoferum $+A$. diazotrophicus $+T$. Viride. Nitrogen and phosphorus uptake in grain and stover was also significantly increased due to combined use of biofertilizers. The maximum $\mathrm{N}$ uptake $\left(59.03 \mathrm{~kg} \mathrm{ha}^{-1}\right.$ in grain and $79.76 \mathrm{~kg}$ $\mathrm{ha}^{-1}$ in stover) and $\mathrm{P}$ uptake was found (9.21 $\mathrm{kg} \mathrm{ha}^{-1}$ in grain and $8.71 \mathrm{~kg} \mathrm{ha}^{-1}$ in stover) (Table 2) with treatment P.fluorescens $+A$. chroococcum $+A$. lipoferum $+A$. diazotrophicus $+T$. Viride. Increased $\mathrm{N}$ and $\mathrm{P}$ uptake was recorded with biofertilizers combinations mainly due to systematic 
activity of biofertilizers to enhance the availability of nutrients (Belimov et al., 1995) by fixation of nitrogen and converting the fixed phosphorus in soil to plant available form (Richardson, 2001) and production of plant growth-regulating hormones (Sahin et al., 2004) and enzymes resulting in improved plant root morphology and physiology (Lugtenberg and Dekkers, 1999). Total N and $\mathrm{P}$ uptake (grain + stover) was to the tune of 138.79 and $17.95 \mathrm{~kg} \mathrm{ha}^{-1}$ respectively, with the combined application of all the biofertilizers together, which was $79 \%$ and $87.96 \%$ (total N and $\mathrm{P}$ ) higher over un-inoculated treatment. This view was consistent with the results of Bashan et al., (2004), Van der Heijden et al., (2006), Farzaneh et al., (2011) with the application of single or combined effect of biofertilizers.

\section{Influence of biofertilizers on grain and stover yield}

Yield (grain and straw) of pearlmillet exhibited significant variation due to use of biofertilizers (Table 2). The highest grain yield (30.1 q ha ${ }^{-1}$ ) and straw yield (107.7 q $\mathrm{ha}^{-1}$ ) was recorded in treatment $(P$. fluorescens $+A$. chroococcum $+A$. lipoferum $+A$. diazotrophicus $+T$. Viride) followed by (A. lipoferum + A. diazotrophicus) and (Azotobacter chroococcum), while lowest yield was observed in control (Un-inoculated). Due to use of biofertilizer combinations grain and stover yield was increased by 79 percent 23 percent respectively over the control. The yield was significantly influenced with the application of biofertilizers (Belimov et al., 1995; Cakmakci et al., 2001) which may be attributed to the increased uptake of nutrients by the plants, improvement of soil characteristics such as contents of organic materials and increase in available nutrient to the crop.Nutrient cycling, decomposition of organic matter, promoting plant growth and health are the major activities of biofertilizers. It was also observed that biofertilizers combined with fertilizer application helped in Nitrogen fixation, phosphate solubilization, production of hormones and antibiotics which were responsible for increased plant growth and yields (Pal, 1999; Asghar et al., 2002 and Ozturk et al., 2003).

Fig.1 Percent change in carbohydrate and protein content of pearlmillet over the control as influenced by the inoculation of biofertilizers

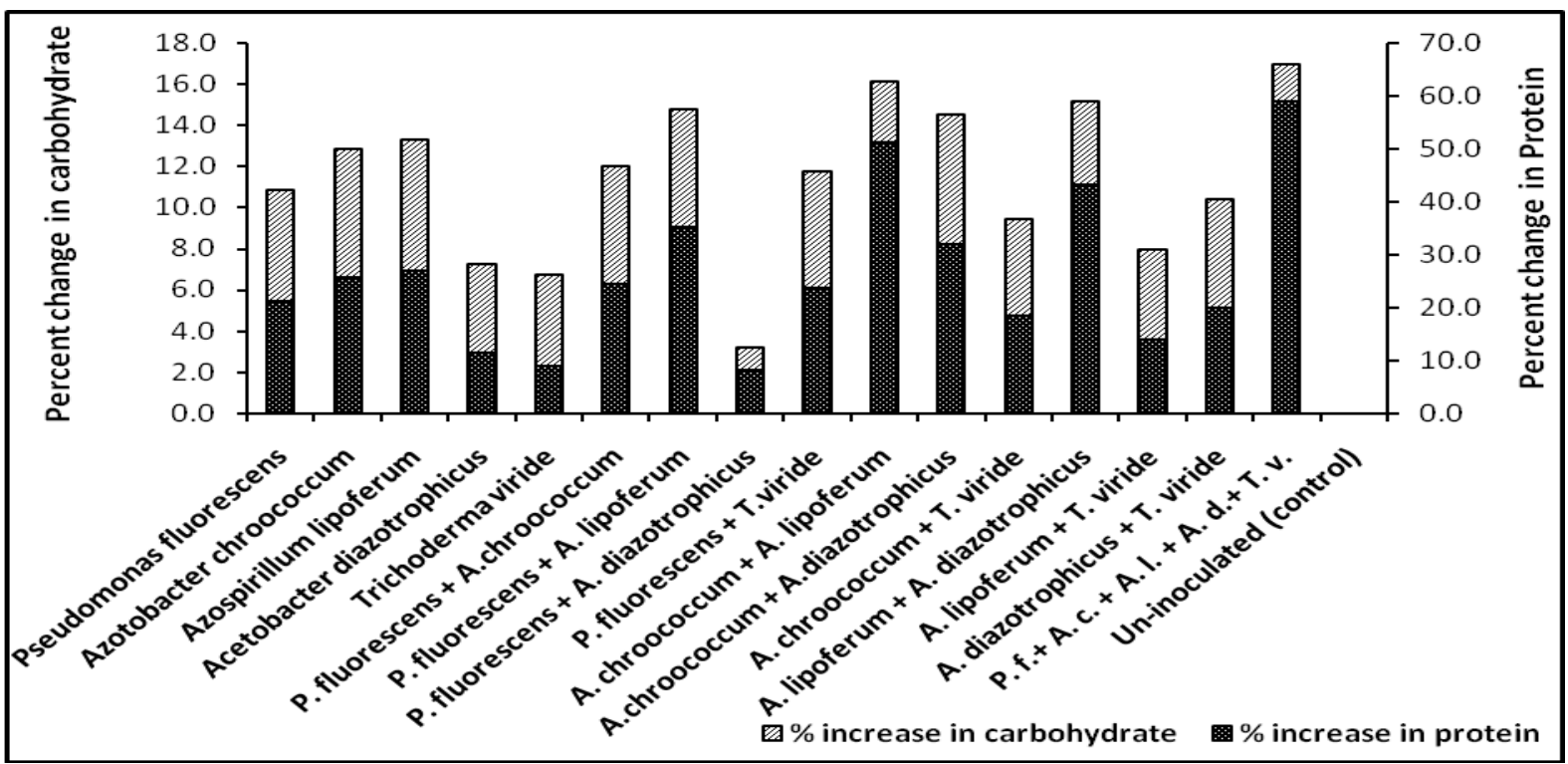


Fig.2 Protein yield $\left(\mathrm{Kg} \mathrm{ha}^{-1}\right)$ of pearl millet as influenced by the inoculation of biofertilizers

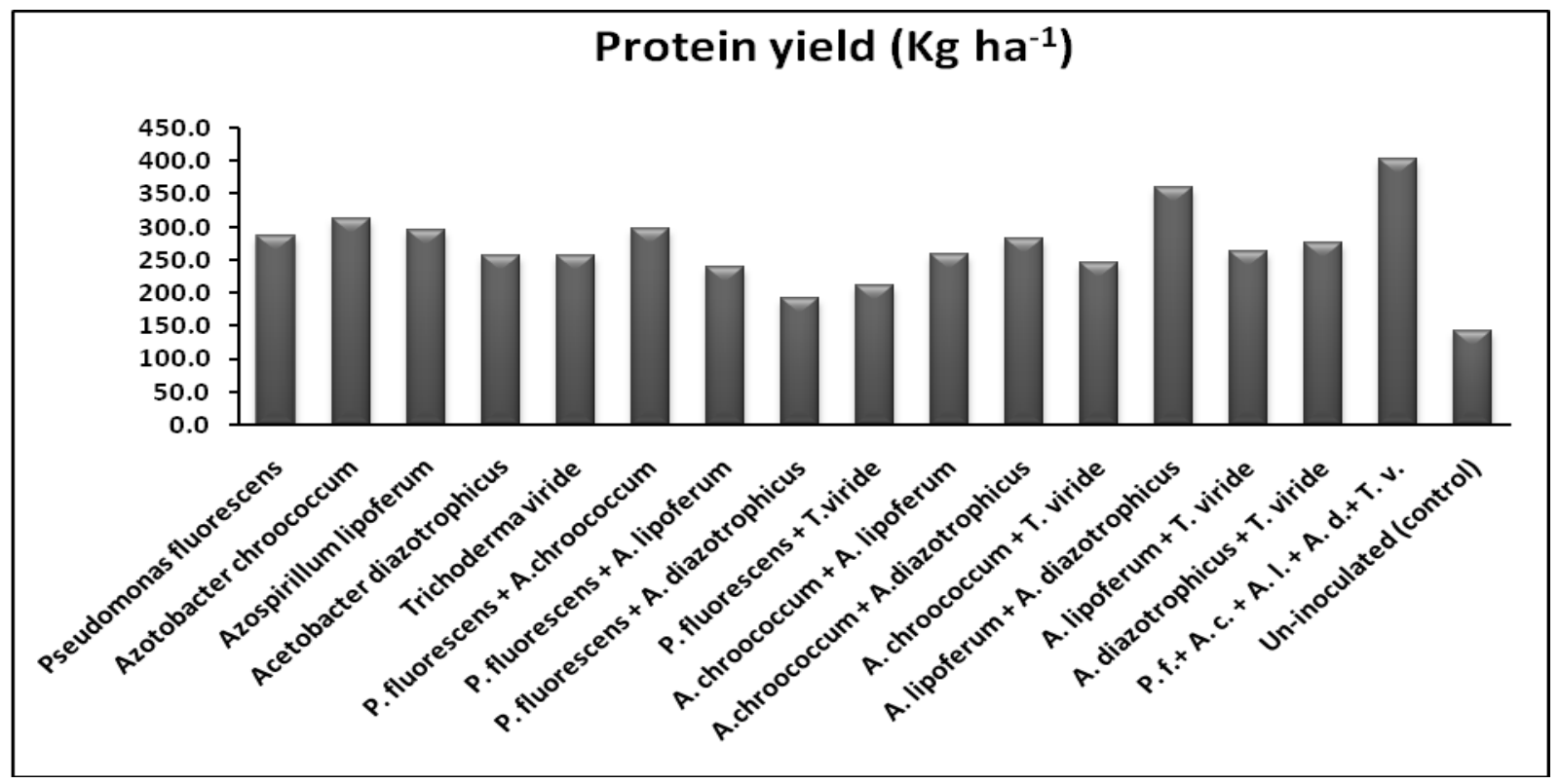

Table.1 Nitrogen and phosphorus content (\%) of Pearlmillet as influenced by the inoculation of biofertilizers

\begin{tabular}{|c|c|c|c|c|}
\hline \multirow[t]{2}{*}{ Treatments } & \multicolumn{2}{|c|}{ Nitrogen content (\%) } & \multicolumn{2}{|c|}{ Phosphorus content (\%) } \\
\hline & Grain & Stover & Grain & Stover \\
\hline Pseudomonas fluorescens & 1.69 & 0.63 & 0.300 & 0.076 \\
\hline Azotobacterchroococcum & 1.82 & 0.71 & 0.282 & 0.067 \\
\hline Azospirillumlipoferum & 1.83 & 0.71 & 0.280 & 0.066 \\
\hline Acetobacter diazotrophicus & 1.70 & 0.69 & 0.277 & 0.063 \\
\hline Trichoderma viride & 1.68 & 0.64 & 0.272 & 0.061 \\
\hline P.fluorescens + A.chroococcum & 1.80 & 0.70 & 0.302 & 0.078 \\
\hline P.fluorescens + A.lipoferum & 1.81 & 0.70 & 0.303 & 0.080 \\
\hline P.fluorescens + A. diazotrophicus & 1.67 & 0.66 & 0.301 & 0.077 \\
\hline P.fluorescens + T.viride & 1.79 & 0.70 & 0.298 & 0.075 \\
\hline A.chroococcum + A.lipoferum & 1.93 & 0.73 & 0.296 & 0.074 \\
\hline A.chroococcum + A.diazotrophicus & 1.86 & 0.72 & 0.290 & 0.072 \\
\hline A.chroococcum $+T$. viride & 1.72 & 0.68 & 0.288 & 0.069 \\
\hline A.lipoferum + A. diazotrophicus & 1.91 & 0.72 & 0.292 & 0.073 \\
\hline A.lipoferum $+T$. viride & 1.69 & 0.67 & 0.284 & 0.068 \\
\hline A. diazotrophicus $+T$. viride & 1.72 & 0.68 & 0.290 & 0.071 \\
\hline$P . f_{0}+A_{.} c_{0}+A_{.} l_{0}+A_{.} d_{0}+T_{.} v_{0}$ & 1.96 & 0.74 & 0.306 & 0.081 \\
\hline Un-inoculated (control) & 1.54 & 0.59 & 0.261 & 0.059 \\
\hline$C D(p=0.05)$ & 0.211 & 0.078 & 0.010 & 0.009 \\
\hline
\end{tabular}

P. f. - Pseudomonas fluorescens (10 $\mathrm{g} \mathrm{kg}^{-1}$ of seed), A. c. - Azotobacter chroococcum ( $25 \mathrm{~g} \mathrm{~kg}^{-1}$ of seed), A. $l$. Azospirillum lipoferum (10 ml kg-1 of seed), A.d. - Acetobacter diazotrophicus (20 $\mathrm{g} \mathrm{kg}^{-1}$ of seed) and T. v. Trichoderma viride (10 $\mathrm{g} \mathrm{kg}^{-1}$ of seed). 
Table.2 Grain yield, straw yield and uptake of nitrogen and phosphorus of pearlmillet as influenced by the inoculation of biofertilizers

\begin{tabular}{|c|c|c|c|c|c|c|c|c|}
\hline \multirow[t]{2}{*}{ Treatments } & \multirow[t]{2}{*}{$\begin{array}{l}\text { Grain } \\
\text { Yield } \\
\left(\mathbf{q} \mathbf{h a}^{-1}\right)\end{array}$} & \multirow[t]{2}{*}{$\begin{array}{l}\text { Stover } \\
\text { Yield } \\
\left(\mathbf{q} \mathbf{h a}^{-1}\right)\end{array}$} & \multicolumn{2}{|c|}{$\begin{array}{l}\text { Nitrogen uptake } \\
\quad\left(\mathrm{Kg} \mathrm{ha}^{-1}\right)\end{array}$} & \multirow{2}{*}{$\begin{array}{l}\text { Total } \\
\text { Nitrogen } \\
\text { uptake } \\
\left(\mathrm{Kg} \mathrm{ha}^{-1}\right)\end{array}$} & \multicolumn{2}{|c|}{$\begin{array}{c}\text { Phosphorus } \\
\text { uptake } \\
\left(\mathrm{Kg} \mathrm{ha}^{-1}\right)\end{array}$} & \multirow{2}{*}{$\begin{array}{c}\text { Total } \\
\text { Phosphorus } \\
\text { uptake } \\
\left(\mathrm{Kg} \mathrm{ha}^{-1}\right)\end{array}$} \\
\hline & & & Grain & Stover & & Grain & Stover & \\
\hline Pseudomonas fluorescens & 27.6 & 92.9 & 47.24 & 58.73 & 105.98 & 8.41 & 7.03 & 15.44 \\
\hline Azotobacter chroococcum & 29.4 & 101.0 & 53.64 & 71.60 & 125.24 & 8.29 & 6.82 & 15.11 \\
\hline Azospirillumlipoferum & 27.4 & 82.2 & 50.11 & 58.56 & 108.67 & 7.68 & 5.43 & 13.11 \\
\hline Acetobacter diazotrophicus & 27.3 & 81.4 & 46.62 & 55.94 & 102.56 & 7.53 & 5.15 & 12.67 \\
\hline Trichoderma viride & 27.8 & 92.7 & 46.77 & 59.26 & 106.04 & 7.56 & 5.64 & 13.20 \\
\hline P.fluorescens + A.chroococcum & 28.2 & 98.3 & 50.63 & 69.14 & 119.77 & 8.54 & 7.66 & 16.19 \\
\hline P.fluorescens + A.lipoferum & 20.8 & 77.6 & 37.66 & 54.02 & 91.68 & 6.32 & 6.23 & 12.55 \\
\hline P.fluorescens + A. diazotrophicus & 21.0 & 84.4 & 35.39 & 55.21 & 90.59 & 6.32 & 6.50 & 12.83 \\
\hline P.fluorescens + T.viride & 20.1 & 83.2 & 36.08 & 58.30 & 94.38 & 6.01 & 6.20 & 12.21 \\
\hline A.chroococcum + A.lipoferum & 20.2 & 79.6 & 39.11 & 58.36 & 97.47 & 5.97 & 5.87 & 11.84 \\
\hline A.chroococcum + A.diazotrophicus & 25.4 & 89.2 & 47.36 & 63.99 & 111.36 & 7.37 & 6.35 & 13.72 \\
\hline A.chroococcum $+T$. viride & 24.5 & 88.8 & 42.39 & 60.91 & 103.30 & 7.08 & 6.15 & 13.23 \\
\hline A.lipoferum + A. diazotrophicus & 29.7 & 102.4 & 56.69 & 73.49 & 130.18 & 8.69 & 7.41 & 16.11 \\
\hline A.lipoferum $+T$. viride & 27.4 & 78.4 & 46.19 & 52.32 & 98.51 & 7.76 & 5.30 & 13.06 \\
\hline A. diazotrophicus $+T$. viride & 27.2 & 88.3 & 46.71 & 59.66 & 106.38 & 7.89 & 6.22 & 14.12 \\
\hline$P . f_{\bullet}+A_{. c}+A_{.} l_{.}+A_{.} d_{.}+T . v_{.}$ & 30.1 & 107.7 & 59.03 & 79.76 & 138.79 & 9.21 & 8.73 & 17.95 \\
\hline Un-inoculated (control) & 16.8 & 87.4 & 25.93 & 51.23 & 77.15 & 4.39 & 5.16 & 9.55 \\
\hline $\mathrm{CD}(\mathrm{p}=0.05)$ & 3.9 & 19.6 & 8.58 & 15.84 & - & 1.01 & 1.49 & - \\
\hline
\end{tabular}




\section{Influence of biofertilizers on quality of grain}

Effect of combined application of biofertilizers was found significant on protein content, but carbohydrate content was not affected significantly. The maximum protein content $(13.43 \%)$ and carbohydrate content $68.7 \mathrm{~g} / 100 \mathrm{~g}$ (Fig. 1) was recorded with the treatment $P$. fluorescens + A. chroococcum + A. lipoferum $+A$. diazotrophicus $+T$. Viride. Compared to un-inoculated treatment, protein and carbohydrate content was increased by $58.9 \%$ and $17 \%$ respectively (Fig. 1).

Protein yield of pearlmillet crop was mainly increased because it was directly related to the yield and protein content of the crop. The maximum protein yield $404.33 \mathrm{~kg} \mathrm{ha}^{-1}$ (Fig. 2) was found with treatment P.fluorescens $+A$. chroococcum $+A$. lipoferum $+A$. diazotrophicus $+T$. Viride.

Previous researchers have proved that biofertilizers are cheapest and most effective tool for obtaining sustainable yields in agriculture (Dakora, 2003), some free-living bacteria were found to have not only the ability to fix nutrients but also the ability to release phytohormones (Sahin et al., 2004) similar to gibberellic acid (Joo et al., 2004) and indole acetic acid, which could stimulate plant growth, absorption of nutrients, and quality of crop. Inoculation with PSB, improved solubilization of fixed soil $\mathrm{P}$ and applied phosphates, resulting in more availability of phosphorus to the plants (Whitelaw et al., 1997; Whitelaw, 2000).

An improvement of yield and quality could be attributed to the high nitrogen uptake by the biofertilizers inoculated plants as well as the ability of the organisms to produce growth promoting substances (Kim et al., 1997).In general, the effect of inoculants was observed to be superior over the control. Growth substances produced by microorganisms might enhance the plant growth, resulting in higher canopy development of plants leading to better utilization of sun rays to convert it into food materials and better root development of plant help to enhance water and nutrient uptake and also provide more strength to plant by increasing the area of rhizosphere.

So, on the basis of above findings it may be concluded that combined inoculation of all biofertilizers might help in increasing the crop yield with better quality (Fukui et al., 1994). The present findings were also corroborated by Bhagchand and Gautam, (2000) who reported that the use of biofertilizer lead to higher availability of nitrogen and phosphorus that promoted growth and development of the crop (Latake et al., 2009) and ultimately resulting in higher yields.

The use of biofertilizers can also substitute a part of chemical fertilizers (Latake et al., 2009) resulting in reducing the pressure of increasing population on the soil and environmental pollution (Karmakar et al., 2007) and also enhancing the sustainability of the system concurrently (Bloemberg et al., 2000).

Biofertilizers are inexpensive and ecologically sound source of plant nutrients. Pearl millet crop due its adverse growing conditions under restricted moisture regimes, often leave untapped nutrients in the soil. So, forreducing the need for chemical fertilizers in agriculture and improving the nutrient use efficiency, it is important to increase and extend the role of biofertilizers for decreasing adverse environmental effects.

On the basis of present investigation and above results it may be concluded that combinations of diazotrophic bacteria Pseudomonas fluorescens, Azotobacter 
chroococcum, Azospirillum lipoferum and Acetobacter diazotrophicus along with Trichoderma viride significantly increased the yield, nutrient content, uptake and quality of pearlmillet crop. Even use of single or combination of two or more biofertilizers might be much advantageous for farmers.

Biofertilizers may help in reducing the soil, water and air pollution by substituting some percentage of chemical fertilizers. Therefore, widespread adoption of biofertilizers may provide a viable solution to the farmers, in securing yield and crop quality without dislocating the natural resources (soil, air and water) and contribute to doubling farmer income and simultaneously attempt to meet the national goal.

\section{References}

Aggarwal, R.K. and Venkateswarlu, J. 1989. Long term effect of manure and fertilizers on important cropping system of arid region. Fertilizer News, 34: 67-70.

Alfano, G., Lewis Ivey, M.L., Cakir, C., Bos, J.I.B., Miller, S.A., Madden, L.V., Kamoun, S., Hoitink, H.A.J. 2007. Systemic modulation of gene expression in tomato by Trichoderma hamatum. Phytopathology, 97: 429-437.

Asghar, H. N., Zahir, Z. A., Arshad, M. and Khaliq, A. 2002. Relationship between in vitro production of auxins by rhizobacteri and their growth promoting activities in Brassica juncea L. Biology and Fertility of Soil, 35: 231-237.

Baghchand, and Gautam, R.C. 2000. Effect of organic manure, biofertilizer and inorganic fertilizer on growth, yield and quality of rainfed pearl millet. Annals of Agriculture Research, 21(4): 459-464.

Bashan, Y., Holguin, G. and De-Bashan, L.E. 2004. Azospirillium-plant relationship: physiological, molecular, agriculture and environmental advances (1997-2003).
Canadian Journal of Microbiology, 50: 521-577

Belimov, A.A., Kojemiakov, P.A. and Chuvarliyeve, C.V. 1995. Interaction between barley and mixed cultures of nitrogen fixing and phosphate solubilizing bacteria. Plant and Soil, 17: 29-37.

Bloemberg, G.V., Wijfjes, A.H.M., Lamers, G.E.M., Stuurman, N. and Lugtenberg, B.J.J. 2000. Simultaneous imaging of Pseudomonas fluorescens WCS3655 populations expressing three different auto fluorescent proteins in the rhizosphere: new perspective for studying microbial communities. Molecular PlantMicrobe Interactions, 13: 1170-1176.

Caballero-Mellado, J., Martínez-Romero, E., de los Santos, P.E., and Fuentes-Ramírez, L.E. 1998. Maize colonization by Acetobacter diazotrophicus. In Biological nitrogen fixation for the 21 st century. Springer, Dordrecht. pp - 381-382.

Cakmakci, R., Kantar, F. and Sahin, F. 2001. Effect of $\mathrm{N}$-fixing bacterial inoculations on yield of sugar beet and barley. Journal of Plant Nutrition and Soil Science, 164: 527-531.

Cattelan, A.J., Hartel, P.G. and Fuhrmann, J.J. 1999. Screening of plant growth promoting rhizobacteria to promote early soybean growth, Soil Science Society of America Journal, 63: 1670- 1680.

Chen, J. 2006. The combined use of chemical and organic fertilizers for crop growth and soil fertility. Int. Workshop on Sustained Management of the Soil Rhizosphere System for Efficient Crop Production and Fertilizer Use. 16-20 October, Thailand.

Dai, J., Becquer, T., Rouiller, J.H., Reversat, G., Bernhard-Reversat, F. and Lavelle, P. 2004. Influence of heavy metals on $\mathrm{C}$ and $\mathrm{N}$ mineralization and microbial biomass in $\mathrm{Zn}-, \mathrm{Pb}-, \mathrm{Cu}-$, and $\mathrm{Cd}$ contaminated soils. Applied Soil Ecology, 25: 99-109. 
Dakora, F.D. 2003. Defining new roles for plant and rhizobial molecules in sole and mixed plant cultures involving symbiotic legumes. New Phytologist, 158(1): 39-49.

Egamberdiyeva, D. 2007. The effect of plant growth promoting bacteria on growth and nutrient uptake of maize in two different soils, Applied Soil Ecology, 36: 184-189.

El-Kholy, M.A. and Gomaa, A.M. 2000. Biofertilizers and their impact on forage yield and $\mathrm{N}$-content of millet under low level of mineral fertilizers. Annals of Agricultural Science, Moshtohor, 38(2): $813-822$.

El-Kholy, M.A., El-Ashry, S. and Gomaa, A.M. 2005. Biofertilization of maize crop and its impact on yield and grains nutrient content under low rates of mineral fertilizers. Journal of Applied Sciences Research, 1(2): 117-121.

Farzaneh, M., Vierheilig, H., Lössl, A. and Kaul, H.P. 2011. Arbuscular mycorrhiza enhances nutrient uptake in chickpea. Plant Soil and Environment, 57(10): 465 -470 .

Fukui, R., Schroth, M.N., Hendson, M., Hancock, J.G. and Firestone, M.K. 1994. Growth patterns and metabolic activity of Pseudomonas in sugar beet spermospheres: Relationship to pericarp colonization by Pythium ultimum. Phytopathology. 84: 1331-1338.

Gomez, K.A. and Gomez, A.A. 1984. Statistical procedures for agricultural research. John Wiley \& Sons.

Harman, G. 2006. Overview of mechanisms and uses of Trichoderma spp. Phytopathology, 96: 190-194.

Hungria, M., Campo, R.J., Souza, E.M. and Pedrosa, F.O. 2010. Inoculation with selected strains of $A$. brasilense and $A$. lipoferum improves yields of maize and wheat in Brazil. Plant and soil. 331: 413425.

Jhala, Y.K., Shelat, H.N., Vyas, R.V. and Panpatte, D.G. 2014. Endophytic bacteria as biofertilizers for maize (Zea mays l.). The Bioscane, 9(3): 1191-1196.

Joo, G.J., Kim, Y.M., Lee, I.J., Song, K. S. and Rhee, I.K. 2004. Growth promotion of red pepper plug seedlings and the production of gibberellins by Bacillus cereus, Bacillus macroides, and Bacillus pumilus. Biotechnology Letters, 26: 487491

Kaewchai, S., Soytong, K. and Hyde, K.D. 2009. Mycofungicides and fungal biofertilizers. Fungal diversity, 38: 25-50.

Karmakar, S., Lague, C., Agnew, J. and Landry, H. 2007. Integrated decision support system (DSS) for manure management. Computers and Electronics in Agriculture, 57: 190-201.

Kennedy, I.R., Choudhury, A.T.M.A. and Kecskes, M.L. 2004. Non-symbiotic bacterial diazotrophs in crop-farming systems: can their potential for plant growth promotion be better exploited? Soil Biology and Biochemistry, 36(8): 1229-1244.

Kim, D.S., Cook, R.J. and Weller, D.M. 1997. Bacillus sp. L324-92 for biological control of three root diseases of wheat grown with reduced tillage. Phytopathology, 87: 551-558.

Latake, S.B., Shinde, D.B. and Bhosale, D.M. 2009. Effect of inoculation of beneficial microorganisms on growth and yield of pearlmillet. Indian Journal of Agriculture Research, 43(1): 61-64.

Lowry, O.H., Ras Brough, N.J., Farr, A.L. and Rondall, R.J. 1951. Journal of Biological Chemistry, 193(1): 265-275.

Lugtenberg, B. and Dekkers, L. 1999. What makes Pseudomonas bacteria rhizosphere competent? Environmental Microbiology, 1: 9-13.

Lugtenberg, B., Chin-A-Woeng, T. and Bloemberg, G. 2002. Microbe-plant interactions: principles and mechanisms. Antonie van Leeuwenhoek, 81: 373-383. 
Mastouri, F., Bjorkman, T. and Harman, G.E. 2010. Seed treatment with Trichoderma harzianum alleviates biotic, abiotic and physiological stresses in germinating seeds and seedlings. Phytopathology, 100: 1213-1221.

Mrkovacki, N. and Milic, V. 2001. Use of Azotobactor chroococcum as potentially useful in agricultural application, Annuals of Microbiology, 51: 145-158.

Nelson, L.M. 2004. Plant growth promoting rhizobacteria (PGPR): prospects for new inoculants. Crop Management, 10: 301305.

Niranjan, S.R., Deepak, S.A., Basavaraju, P., Shetty, H.S., Reddy, M.S. and Kloepper, J.W. 2003. Comparative performance of formulations of plant growth promoting rhizobacteria in growth promotion and suppression of downy mildew in pearl millet. Crop Protection, 22: 579- 588.

Niranjan, S.R., Shetty, N.P. and Shetty, H.S. 2004. Seed bio-priming with Pseudomonas fluorescens isolates enhances growth of pearl millet plants and induces resistance against downy mildew. International Journal of Pest Management, 50(1): 41-48.

Olsen, S.R. 1954. Estimation of available phosphorus in soils by extraction with sodium bicarbonate. United States Department of Agriculture; Washington.

Ozturk, A., Caglar, O. and Sahin, F. 2003. Yield response of wheat and barley to inoculation of plant growth promoting rhizobacteria at various levels of nitrogen fertilization. Journal of Plant Nutrition and Soil Science, 166: 262-266.

Pal, S.S.1999. Interaction of an acid tolerant strain of phosphate solubilizing bacteria with a few acid tolerant crops. Plant and Soil, 213: 221-230.

Pandya, U. and Saraf, M. 2010. Application of fungi as a biocontrol agent and their biofertilizer potential in agriculture.
Journal of Advance Development and Research, 1(1): 90-99.

Parihar, C.M., Rana, K.S. and Kantwa, S.R. 2010. Nutrient management in pearlmillet (Pennisetum glaucum)-Mustard (Brassica juncea) cropping system as affected by land configuration under limited irrigation. Indian Journal of Agronomy, 55(3): 191.

Persello-Cartieaux, F., Nussaume, L. and Robaglia, C. 2003. Tales from the underground: molecular plantrhizobacteria interactions. Plant Cell and Environment, 26(2):189-199.

Raju, N.S., Niranjana, S.R., Janardhana, G.R., Prakash, H.S., Shetty, H.S. and Mathur, S.B. 1999. Improvement of seed quality and field emergence of Fusarium moniliforme infected sorghum seeds using biological agents. Journal of the Science of Food and Agriculture, 79: 206-212.

Ram Rao, D.M., Kodandaramaiah, J., Reddy, M.P., Katiyar, R.S. and Rahmathulla, V.K. 2007. Effect of VAM fungi and bacterial biofertilizers on mulberry leaf quality and silkworm cocoon characters under semiarid conditions. Caspian Journal of Environmental Sciences, 5(2): 111-117.

Richardson, A.E. 2001. Prospects for using soil microorganisms to improve the acquisition of phosphorus by plants, Australian Journal of Plant Physiology, 28: 897-906.

Sahin, F., Cakmakci, R. and Kantar, F. 2004. Sugar beet and barley yields in relation to inoculation with $\mathrm{N}$-fixing and phosphate solubilizing bacteria. Plant and Soil, 265: 123-129.

Salantur, A., Ozturk, A. and Akten, S. 2006. Growth and yield response of spring wheat (Triticum aestivum L.) to inoculation with rhizobacteria, Plant Soil and Environment, 52: 111-118. 
Scheiner, J.D., Gutie'rrez-Boem, F.H. and Lavado, R.S. 2002. Sunflower nitrogen requirement and $15 \mathrm{~N}$ fertilizer recovery in Western Pampas, Argentina. European Journal of Agronomy, 17: 73-79.

Seema, P., Chandra, K.K., Tiwari, K.P. and Paroha, S. 2000. Synergistic role of VAM and Azotobacter inoculation on growth and biomass production in forestry species. Journal of Tropical Forestry, 16: $13-21$

Sexsena, A. 1997. Response of pearlmillet to inoculation with biofertilisers in the Indian arid zone. ProceedingsSymposium-Recent Advances in Arid Ecosystem, Jodhpur, India (March 3-5) 283-286.

Sharma, K.A. 2012. A handbook of organic farming, Agrobios (India), pp. 269.

Singh, C., Singh, P. and Singh, R. 2009. Pearlmillet, Modem techniques of raising field crops, ISBN 81-204-1599 pp. 131146.

Sonawane, P.D., Wadile, S.C., Girase, P.P., Chitodkar, S.S. and Sonawane, D.A. 2010. Response of summer pearlmillet (Pennisetum glauchum L.) to depth and time of irrigation scheduling. International Journal of Agricultural Sciences, 6(1): 283-285.

Subbaiah, V.V. and Asija, G.K. 1956. A rapid procedure for utilization of available nitrogen in soil. Current Science, 26, 258260.

Tambekar, D.H., Gulhane, S.R., Somkuwar, D.O., Ingle, K.B. and Kanchalwar, S.P.
2009. Potential Rhizobium and phosphate solubilizers as a biofertilizers from saline belt of Akola and Buldhana district, India. Research Journal of Agriculture and Biological Sciences, 5(4): 578-582.

Urquiaga, S., Cruz, K.H.S. and Boddey, R.M. 1992. Contribution of nitrogen fixation to sugar cane: nitrogen-15 and nitrogenbalance estimates. Proceedings of Soil Science Society of America, 56: 105-114. Van der Heijden, M.G.A., Streitwolf-Engel, R., Riedl, R., Siegrist, S., Neudecker, A., Ineichen, K., Boller, T., Wiemken, A. and Sanders, I.R. 2006. The mycorrhizal contribution to plant productivity, plant nutrition and soil structure in experimental grassland. New Phycologist, 172: 739-752.

Wani, P.V. 1990. Pandit Jawaharlal Nehru Centenary National Seminar held at Aurangabad, Oct. 14-16.

Whitelaw, M.A. 2000. Growth promotion of plants inoculated with phosphatesolubilizing fungi. Advances in Agronomy, 69: 99-151.

Whitelaw, M.A., Hardenand, T.A. and Bender, G.L. 1997. Plant growth promotion of wheat inoculated with Penicillium radicum sp. Australian Journal of Soil Research, 35: 291-300.

Zahir, A., Arshad, Z.M, and Frankenberger, W.F. 2004. Plant growth promoting rhizobacteria: applications and perspectives in agriculture. Advances in Agronomy, 81: 97-168.

\section{How to cite this article:}

Durgesh Singh, Krishna Raghuvanshi, Asheesh Chaurasiya, Swaraj Kumar Dutta and Santosh Kumar Dubey. 2018. Enhancing the Nutrient Uptake and Quality of Pearlmillet (Pennisetum glaucum L.) through Use of Biofertilizers. Int.J.Curr.Microbiol.App.Sci. 7(04): 3296-3306. doi: https://doi.org/10.20546/ijcmas.2018.704.373 